on half-pay. Even the fighting Téméraire was towed up the Thames to be broken up, as depicted by J. M. W. Turner. Barrow's solution was to send them exploring - up the Congo, down the Niger, even to Timbuctoo, and most especially to the far north in search of the fabled north-west passage, the mysterious link between Europe and the Pacific Ocean that would open new trading routes and halve the time taken to reach desirable eastern ports. Barrow's boys were the great naval explorers William Parry, Edward Belcher, John and James Ross, John Franklin, Richard Lander, John Rae and many, many more. One by one, they set out to fulfil Barrow's obsession with filling in blank parts on the Admiralty maps.

The folly of the expeditions described here was extraordinary, the heroism quite stunning. John Ross took a small steamship into Prince Regent Inlet and was stuck in the ice for four winters, spending one season moving no more than 300 yards. Belcher set out with four ships and returned with one. Half of Franklin's first expedition starved to death. George Back went north to save Ross only to discover that, while he iced over at Great Slave Lake, Ross had arrived home. Franklin's third voyage ended with all hands perishing. James Tuckey died in the Congo, Hugh Clapperton died in the Niger, Gordon Laing was murdered in Timbuctoo. Barrow's explorers showed astonishing stoicism and courage in the face of adversity.

Fleming describes some 26 expeditions master-minded by Barrow, including African, Arctic and Antarctic voyages, ranging from Tuckey's inland explorations in 1816 to the final polar voyage in search of Franklin's body, whose death was at last confirmed by Leopold McClintock in 1857. He writes in a thoroughly readable style, full of telling anecdotes, halfamused by the ingenuity of his travellers, critical of their follies and deeply conscious of the extreme rigours they experienced. These stories have been told often enough before, but the strength of Fleming's account is his colourful interlacing of the individual travellers' personal stories. Each voyage spills into the next, with young lieutenants on one expedition ascending the ranks to command another, and with the motif of the solitary, driven, Admiralty man behind them.

What is gained by the personal, however, is partly lost for the domain of science. Few of the scientific achievements of the voyages are described in any detail. It would be hard to unpack the role of the Royal Society of London from these adventurous chapters, for example, in supplying instructions for magnetic and astronomical observations, natural history collections, directives for anthropological encounters and geographical problems to resolve. It would be equally hard to get a clear grasp of the political situation which took Britain from the Napoleonic Wars to William IV (the sailor king) and George
Canning, on to Queen Victoria. Barrow's part in establishing the Royal Geographical Society is scarcely touched on, nor is his baronetcy in 1835 . Other voyages of a similarly dramatic nature were sent out by Francis Beaufort of the Hydrographer's Office, most notably the Beagle. And more could be said, no doubt, about the exploitative, self-aggrandizing territorial thrust of the British during this period. Science, exploration and national desires were closely intermeshed. The Admiralty's skill in distributing these coiling economic threads across the nineteenthcentury globe is indisputable.

But it would be churlish to go on. Barrow's Boys is a wonderful story, vividly told. Every amateur yachtsman of my acquaintance will be getting a copy for Christmas. $\square$ Janet Browne is at the Wellcome Institute for the History of Medicine, 183 Euston Road, London NW1 2BE, UK.

\section{To party, or don the anorak?}

\section{Mapping Time: The Calendar and Its History \\ by E. G. Richards \\ Oxford University Press: 1998.438 pp. $£ 20$, \\ $\$ 33.49$ \\ The Calendar: The 5000-Year Struggle To Align the Clock and the Heavens - and What Happened to the Missing Ten Days}

by David E. Duncan

Fourth Estate: 1998.306 pp. $£ 12.99$

\section{Jim Bennett}

If there is any sensible focus for the millennium, it has to be the calendar, perhaps linked to our interest in what we take to be 'round' numbers. Yet deconstructing the foundation for millennium fever has to go further, for the event occurs in only one particular calendar. Even then, the beginning of the millennium will be identified only according to the current adjustment or finer tuning of that calendar; and all of those doubts come before we might begin to be troubled over which year marks the real beginning.

Has there ever been so much fuss over what is, in the end, a social convention? One reasonable prognostication might be that the vague notion that the millennium will somehow mark the beginning of something more than a different-looking set of numbers is bound to lead to disappointment and disillusion. A harmless response to the hype might be to exchange the party clothes for the anorak, and become surprisingly knowledgeable about the calendar. These books offer alternative ways to begin.

Neither work really admits to a strong millennial mission, although E. G. Richards reassures us that he has noticed something afoot: "I am aware that soon the world will celebrate the start of a new millennium." But it is hard not to imagine that, at least as far as the publishers are concerned, the big $\mathrm{M}$ has influenced these publications, aimed as they are at the popular market.

Mapping Time is reliable in its factual content, but not very analytical, and the facts are dispensed with little sense of historical or cultural context. It reads rather like an encyclopaedia, without adopting that format. Each category is treated in turn in successive chapters without there being a strong narrative structure. It is not a book to be read, but to be consulted on particular topics.

The Calendar, although written in too uncritical a style to be taken seriously as history, has a stronger chronological organization and relies on historical anecdote to keep the narrative moving. Consequently, it is easier to read. It tells the story from the Stone Age to the Gregorian reform of the sixteenth century, and then steps nimbly on to conclude with the atomic clock. It offers a romp through history with calendars as the connecting thread.

Neither book has very seriously scholarly pretensions, although Richards's encyclopaedic approach makes it more strongly weighted with facts and it has a stronger guide to the literature. Both seem to subscribe to a forward, progressive dynamic of science overcoming dogma and superstition with observation and rational thought. This makes their link to the coming millennium somewhat ironic, or perhaps the authors' coyness about any link understandable. Jim Bennett is at the Museum of the History of Science, Broad Street, Oxford OX1 3AZ, UK.

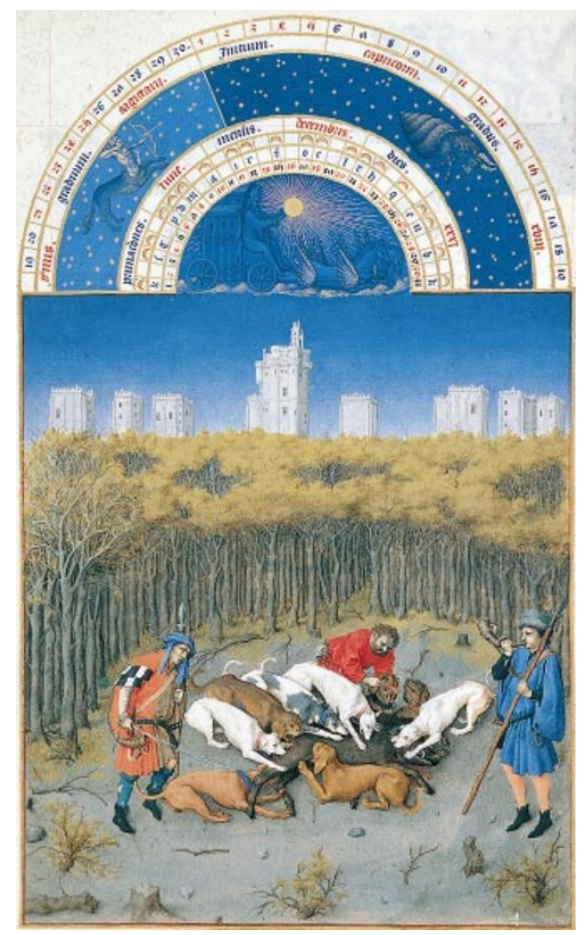

Marking time: Boar hunting was a December pastime in the fifteeenth century. 